\title{
Variation in bioactive content in broccoli (Brassica oleracea var. italica) grown under conventional and organic production systems
}

\begin{tabular}{|r|l|}
\hline Journal: & Journal of the Science of Food and Agriculture \\
\hline Manuscript ID: & JSFA-14-0882.R1 \\
\hline Diley - Manuscript type: & Research Article \\
\hline Complete List of Authors: & $\begin{array}{l}\text { Valverde, Juan; Monaghan Mushrooms, Research } \\
\text { Reilly, Kim; Teagasc, Food Research Centre } \\
\text { Villacreces, Salvador; Teagasc, Food Research Centre } \\
\text { Gaffney, Michael; Teagasc, Food Research Centre } \\
\text { Grant, Jim; Teagasc, Food Research Centre } \\
\text { Brunton, Nigel; University College Dublin, School of Agriculture and Food } \\
\text { Science }\end{array}$ \\
\hline Key Words: & $\begin{array}{l}\text { Brassica oleracea, organic agriculture, glucosinolates, neoglucobrassicin, } \\
\text { glucobrassicin, phenolic compounds }\end{array}$ \\
\hline &
\end{tabular}


1 Variation in bioactive content in broccoli (Brassica oleracea var. italica) grown under

2 conventional and organic production systems

3

4 Running title: organic_broccoli_JSFA

5

6 Juan Valverde, ${ }^{*}{ }^{1,2}$ Kim Reilly, ${ }^{*}$ Salvador Villacreces, ${ }^{1}$ Michael Gaffney, ${ }^{1}$ James Grant, ${ }^{1}$ and

$7 \quad$ Nigel Brunton ${ }^{1,3}$

8

$9 \quad *$ Both authors contributed equally

10

$11{ }^{1}$ Teagasc, Ashtown Food Research Centre, Ashtown, Dublin 15, Ireland.

$12{ }^{2}$ Monaghan Mushrooms, Tyholland, Co. Monaghan, Ireland.

$13{ }^{3}$ School of Agriculture and Food Science, University College Dublin, Ireland.

14

15

16

17

18

19

20

21

22

23

24 Correspondence: Dr Kim Reilly, Teagasc Food Research Centre, Ashtown, Dublin 15, 25 Ireland. Tel: +353 (0) 180599 50, e-mail: kim.reilly@teagasc.ie 
27 BACKGROUND: Broccoli and other cruciferous vegetables contain a number of bioactive 28 compounds - in particular glucosinolates and polyphenols, which are proposed to confer 29 health benefits to the consumer. Demand for organic crops is at least partly based on a 30 perception that organic crops may contain higher levels of bioactive compounds; however 31 insufficient research has been carried out to either support or refute such claims.

32 RESULTS: In this study we examined the effect of conventional, organic, and mixed 33 cultivation practices on the content of total phenolics, total flavonoids, and total and 34 individual glucosinolates in two varieties of broccoli grown over two years in a split-plot 35 factorial systems comparison trial. Levels of total phenolics and total flavonoids showed a 36 significant year on year variation but were not significantly different between organic and 37 conventional production systems. In contrast, levels of the indolyl glucosinolates 38 glucobrassicin and neoglucobrassicin were significantly higher $(\mathrm{p}<0.05)$ under fully organic 39 compared to fully conventional management.

40 CONCLUSION: Organic cultivation practices resulted in significantly higher levels of 41 glucobrassicin and neoglucobrassicin in broccoli florets, however other investigated 42 compounds were unaffected by production practices.

Keywords: Brassica oleracea; organic agriculture; glucosinolates; neoglucobrassicin; glucobrassicin; phenolic compounds. 


\section{INTRODUCTION}

52 Over the last 10 years demand for organically produced food products has increased and this

53 has been recognized as an important consumer trend in the USA and Europe. ${ }^{1}$ Although the

54 reasons behind this increasing demand differ among countries and consumer groups, the 55 perception of improved animal welfare, environmental protection, and food quality 56 characteristics (including health, nutritional and/or sensory attributes) are among some of the 57 reasons cited for this trend. ${ }^{1,2}$ Organic crop production in the European Union is carried out 58 under strictly defined production practices. ${ }^{3,4}$ Despite consumer presumption that organic 59 fruits and vegetables are healthier, the reality is that previous studies on nutrient and 60 phytochemical composition have shown contradictory results. ${ }^{5-12}$ One of the main challenges 61 for these types of studies is the design of a robust experiment that takes account of important 62 factors which can contribute to variability between studies such as crop variety, geographical 63 location, growth season, management practices used, experimental design and statistical 64 power.

65 Levels of glucosinolates and phenolic compounds in broccoli appear to be affected 66 primarily by variety although only a few studies have been carried out with a number of 67 cultivars examined under uniform cultivation conditions. ${ }^{13-17}$ Levels are also affected by 68 factors such as nitrogen fertilization, environmental factors and season, ${ }^{18-2}$ although levels of 69 both phenolic compounds and glucosinolates appear to remain stable under post-harvest 70 storage treatments designed to simulate commercial storage and marketing. ${ }^{22}$

71 Broadly three types of study have been used to examine differences in nutritional or 72 phytochemical content between organic and conventional foods. The first type comprise 73 basket surveys, in which sampling is made at retail points, by grouping samples according to 74 production system e.g. ${ }^{9}$ The second type of study uses matched paired farms where existing 75 farms using either conventional or organic production systems are matched as far as possible 
76 in terms of location and crop produced. ${ }^{23}$ The last type of study is by performing replicated

77 field trials. ${ }^{24}$ In any of these types of study a number of uncontrolled factors can influence 78 the results obtained. Consequently, contradictory results have been obtained between different 79 studies. In an extensive and widely reported meta-analysis Dangour et al. ${ }^{5}$ note the 80 difficulties and variable quality of research in the area and suggest five criteria for a study of 81 acceptable quality: firstly to clearly define the organic production methods including the name 82 of the certification body; secondly to specify crop cultivar or animal breed; thirdly to state 83 which nutritionally relevant substance was analysed; fourthly to state methods of analysis and 84 lastly to state methods used for statistical analyses.

85 The aim of this study was to compare the content of glucosinolates and phenolic 86 compounds in organically and conventionally grown broccoli (Brassica oleracea var. italica).

87 88 89

90

91

92

\section{MATERIALS AND METHODS}

\section{Experimental design}

Two varieties each of broccoli, carrot and onion were grown in a replicated split-plot systems comparison trial. The field trial has a factorial design which divides both organic and conventional production systems into component soil management and pest-control practices. It was designed to investigate the effect of, and any interaction between, production system components - a) soil management and b) pest-control measures, that differ between organic and conventional systems. In order to encompass seasonal variation, sampling and data analysis presented is on two years of crop production. The trial design and statistical analyses comply with the suggested quality criteria of Dangour et al. ${ }^{5}$ The trial design includes fully organic, fully conventional and mixed treatments, which allows comparison of fully organic and fully conventional production, whilst allowing investigation of soil and pest-control 
100 components which make up organic or conventional agricultural practices. Management

101 practices used are summarised in Table 1.

\section{$102 \quad$ Plant material}

103 Broccoli samples for this study were grown in 2009 (year1) and 2010 (year 2). Varieties

104 selected were cv. 'Belstar' and cv. 'Fiesta' both of which are commercial varieties commonly 105 grown by conventional and organic growers in Ireland. Plants were grown according to 106 cultivation practices in compliance with European and Irish standards for organic certification 107 (Irish Organic Farmers and Growers Association (IOFGA) and Organic Trust standards, see 108 details below) and/or following the Irish Agriculture and Food Development Authority 109 (Teagasc) recommendations for conventional practices. ${ }^{25,} 26$ The year 1 broccoli crop was 110 Sown on $24^{\text {th }}$ April, transplanted on $25^{\text {th }}$ June and harvested between $4^{\text {th }}$ and $25^{\text {th }}$ September 111 2009. The year 2 crop was sown on $23^{\text {rd }}$ March, transplanted on $18^{\text {th }}$ May and harvested 112 between $27^{\text {th }}$ July and $5^{\text {th }}$ August 2010. Plants were produced as modular transplants in 216 113 trays and transplanted at $40 \mathrm{~cm}$ in-row spacing with 2 rows per $1.52 \mathrm{~m}$ bed. External rows

114 were treated as guard rows with samples harvested from internal rows only. Specific applied 115 inputs for broccoli propagation and cultivation are shown in Table 2. Climatic conditions 116 during the growing season in both years are shown in supplementary material (Table S1). 117 Additional information on the field trial is available at

118 http://www.ipfn.ie/publications/agronomic/.

119 For each experimental plot broccoli was harvested at commercial maturity from the 120 internal rows with guard rows excluded. The mean floret weight was calculated as the total 121 weight of harvested broccoli florets divided by the number of florets. Samples for analysis 122 were primary florets of similar size and were immediately refrigerated and then frozen at $12320^{\circ} \mathrm{C}$ within 24 hours of harvest. Samples from each experimental plot were composite 124 samples comprising three healthy, disease free florets of marketable quality. 


\section{$126 \quad$ Field trial}

127 The field trial is located at Teagasc Kinsealy Research Centre, Kinsealy $\left(53^{\circ} 25^{\prime} \mathrm{N}\right.$

128 Lat $\left.6^{\circ} 10^{\prime} \mathrm{W}\right)$, in north county Dublin, Ireland. Soil type was characterised as loam to clay

129 loam belonging to the grey brown podzolic soil group and with a high base status (Altitude:

13028 metres O.D. (ordnance datum), Slope: $1^{\mathrm{o},}$ Drainage: Moderately well drained). Soil type

131 was consistent across the experimental trial site as indicated by a previous detailed soil map

132 of the area. ${ }^{27}$ Equivalent rates of nitrogen $(\mathrm{N})$, phosphorus $(\mathrm{P})$ and potassium $(\mathrm{K})$ were

133 applied to both conventional and organic soil treatments for each crop and the rates applied

134 were according to Teagasc published recommendations for the crop. ${ }^{25}$ Although the amount

135 of $\mathrm{N}, \mathrm{P}$ and $\mathrm{K}$ supplied was identical between systems, plant availability and uptake is

136 affected by fertilizer form (chemical vs. organic) due to differences in water solubility and the

137 need for organic fertilizer to be broken down by soil microbes. The trial was established in

138 spring 2009 on land which had previously been under grass set-aside for over 10 years. The

139 same irrigation source was used for the whole trial.

140 The trial was a $2 \times 2 \times 2$ factorial split-plot design, with 4 replicates (blocks). Variety

141 was assigned as the main plot, with pest-control and soil treatment assigned as sub plots. Two

142 varieties (V1, V2) of 3 crops (carrots, broccoli and onion) were grown in each year. There

143 were two levels of soil treatment - an organic soil treatment (OS) and a conventional soil

144 treatment (CS); and 2 levels of pest control - an organic pest-control treatment (OP) and a

145 conventional pest-control treatment (CP).

146 The OS treatment comprised certified organic fertilizer inputs, a 4 year horticultural 147 crop rotation including a red clover ley (Trifolium repens) and use of winter cover crops

148 (Table 1). The CS treatment comprised use of mineral fertilizers, with no set crop rotation.

149 Equivalent rates of nitrogen $(\mathrm{N})$, phosphorus $(\mathrm{P})$ and potassium $(\mathrm{K})$ were applied to both CS 
150 and OS treatments for each crop following a spring soil test and rates were according to

151 Teagasc recommendations for the crop. ${ }^{25}$ Fertilizer was applied as calcium ammonium nitrate 152 (CAN), single super-phosphate and sulphate of potash for the CS treatment, or Greenvale 153 (3:3:1) and ProKali (3:0:14) for the OS treatment. Specific inputs are shown in Table 2. Pest-control measures were required for control of weeds, cabbage root-fly (Delia radicum), and caterpillars of Diamond-back moth (Plutella xylostella) and Large White 156 butterfly (Pieris brassicae). Organic pest-control (OP) measures comprised mechanical (e.g. 157 hand hoeing, brassica collars) and certified organic treatments as shown in Table 2. 158 Conventional pest-control (CP) treatments involved a chemical spay programme and were in 159 accordance with an Integrated Pest Management plan, in keeping with commercial growing 160 practises in North Dublin.

161 Within each replicate $(n=4)$ each crop is grown under 8 possible treatment 162 combinations $(\mathrm{V} 1+\mathrm{OS}+\mathrm{OP}, \quad \mathrm{V} 1+\mathrm{OS}+\mathrm{CP}, \quad \mathrm{V} 1+\mathrm{CS}+\mathrm{OP}, \quad \mathrm{V} 1+\mathrm{CS}+\mathrm{CP}, \quad \mathrm{V} 2+\mathrm{OS}+\mathrm{OP}$, $163 \mathrm{~V} 2+\mathrm{OS}+\mathrm{CP}, \mathrm{V} 2+\mathrm{CS}+\mathrm{OP}, \mathrm{V} 2+\mathrm{CS}+\mathrm{CP})$ giving a total of 32 plots per crop per year 164 (Supplementary material Figures S1, S2). The organic cultivation practices used were in 165 compliance with EC $834 / 2007^{3}$ and with national standards for organic certification set out 166 by the Irish organic certification bodies (IOFGA and the Irish Organic Trust) with the 167 exception that for experimental purposes the separation distance (generally $50 \mathrm{~m}$ ) required 168 between adjacent organic and conventional enterprises was not practised between organic and 169 conventional treatment plots.

170 Each experimental plot comprised two $1.52 \mathrm{~m}$ beds of $5.5 \mathrm{~m}$ length (area $16.7 \mathrm{~m}^{2}$ ). In 171 order to prevent or reduce as far as possible any cross contamination between treatment plots, 172 within each replicate each plot was separated from neighbouring treatment plots by a $1 \mathrm{~m}$ 173 wide untreated grass inter-plot area, with $3 \mathrm{~m}$ grass areas between replicate blocks. Fertilizers 174 were applied by hand and tractor tillage operations carried out such as to minimise movement 
175 of soil between treatments. Pesticides were applied using a knapsack sprayer with hood to

176 prevent spray drift between treatment plots. Although it was not practically feasible to

177 completely prevent all movement between plots (e.g. arthropods, earthworms, microbes could

178 be expected to move through the soil to some extent) statistically significant differences in

179 soil microbial activity and functional diversity between plots under different management

180 practices has been demonstrated in this trial ${ }^{28}$ indicating that measures used were effective in

181 allowing different soil biology in different plots.

182 Diagrams showing the plot allocation and crop rotation in years 1 and 2 are shown in 183 supplementary material Figures S1 and S2.

184

\section{Total phenolics and total flavonoids}

186 For the determination of total phenolics a modification of the Folin-Ciocalteau method was

187 used. Briefly, broccoli samples were ground to a fine powder under liquid nitrogen. Frozen

188 tissue $(0.50 \mathrm{~g})$ was transferred to a falcon tube and $5 \mathrm{~mL}$ of $80 \%$ methanol $(\mathrm{v} / \mathrm{v})$ was added.

189 Tubes were vortexed thoroughly and allowed stand at room temperature for 20 minutes.

190 Tubes were mixed by inversion and $1.5 \mathrm{~mL}$ aliquots of extract were transferred to a microfuge

191 tube. Microfuge tubes were centrifuged at $12,000 \mathrm{~g}$ for 5 minutes at $4{ }^{\circ} \mathrm{C}$ and the supernatant

192 was transferred to a fresh tube. For each sample $150 \mu \mathrm{L}$ of the methanolic extract, $150 \mu \mathrm{L} 80$

$193 \%(\mathrm{v} / \mathrm{v})$ methanol, $150 \mu \mathrm{L}$ Folin-Ciocalteau reagent and $1050 \mu \mathrm{L}$ sodium carbonate solution

$194(20 \% \mathrm{w} / \mathrm{v})$ were pipetted into a microfuge tube, votexed and placed in the dark at room

195 temperature for 20 minutes. Tubes were centrifuged at 12,000g for 3 minutes and the

196 supernatant was transferred to a fresh tube. The absorbance at $725 \mathrm{~nm}\left(\mathrm{~A}_{725}\right)$ was determined

197 relative to a blank containing $80 \%(\mathrm{v} / \mathrm{v})$ methanol instead of extract, and the concentration

198 was determined from a calibration curve using gallic acid. Results are expressed as gallic acid

199 equivalents on a fresh weight basis (GAE mg/100g FW). 
200 Determination of flavonoids was according to Marinova et al. ${ }^{29}$ For each sample 150 $201 \mu \mathrm{L}$ of the methanolic extract and $600 \mu \mathrm{L}$ MilliQ water were added to a microfuge tube and 202 mixed by inversion. To each tube $45 \mu \mathrm{L}$ of $5 \%$ sodium nitrite $\left(\mathrm{NaNO}_{2}\right)$ was added and tubes 203 were incubated at room temperature for 5 minutes. To each tube $45 \mu \mathrm{L}$ of $10 \%$ aluminium 204 chloride was added and tubes incubated for a further 1 minute. Subsequently $300 \mu \mathrm{L}$ of $1 \mathrm{M}$ 205 sodium hydroxide $(\mathrm{NaOH})$ and $360 \mu \mathrm{L}$ MilliQ water was added and tubes mixed vigorously. 206 The absorbance at $510 \mathrm{~nm}\left(\mathrm{~A}_{510}\right)$ was measured relative to a blank containing $80 \%(\mathrm{v} / \mathrm{v})$ 207 methanol instead of extract, and flavonoid concentration was determined from a standard 208 curve using catechin as a standard. Results are expressed as catechin equivalents (CE $209 \mathrm{mg} / 100 \mathrm{~g} \mathrm{FW})$.

210

\section{Glucosinolate extraction}

212 Frozen broccoli samples were freeze dried in a large scale freeze drier (Frozen in Time Ltd.

213 United Kingdom). Once freeze dried, samples were milled, vacuum packed in polypropylene

214 bags and kept at $-80^{\circ} \mathrm{C}$ until analysis. Glucosinolates were extracted from freeze-dried 215 broccoli powder using pressurised liquid extraction with an ASE 200 instrument (Dionex; 216 Sunnyvale, CA, USA) with attached solvent controller. Glucosinolate extraction was carried 217 out in $22 \mathrm{~mL}$ steel cartridges packed with a mixture of freeze-dried broccoli $(1.00 \mathrm{~g})$ and 218 technical grade silica to disperse sample. Extraction conditions were as described in 219 Hernandez-Hierro et al. ${ }^{30}$

220 Sulphatase extraction procedure

221 Sulphatase (Type H-1 from Helix pomatia, Sigma, MO, USA) was purified by dissolving the 222 sulphatase powder $(70 \mathrm{mg})$ in deionised water $(3 \mathrm{~mL})$ and adding ethanol $(3 \mathrm{~mL})$. This 223 solution was centrifuged (12000 rpm, $10 \mathrm{~min}$, room temperature) and to the supernatant 224 ethanol ( $9 \mathrm{~mL})$ was added after which the solution was centrifuged (12000 rpm, $10 \mathrm{~min}$, room 
225 temperature) again. The pellet was dissolved in deionised water $(2 \mathrm{~mL})$ and this sulphatase

226 solution was subsequently passed through a $0.5 \mathrm{~mL}$ DEAE Sephadex A-25 and a $0.5 \mathrm{~mL}$ SP

227 Sephadex C-25 column. This solution was collected in a vial and kept at $-80{ }^{\circ} \mathrm{C}$ until use.

228 An aliquot $(1 \mathrm{~mL})$ of glucosinolate extract was applied to a DEAE Sephadex A-25 column

$229(0.5 \mathrm{~mL})$ and the unbound material was removed by washing with deionised water $(2 \times 1 \mathrm{~mL})$

230 and sodium acetate buffer $(2 \times 0.5 \mathrm{~mL}, 20 \mathrm{mM}, \mathrm{pH} 5.0)$. After washing, purified sulfatase

231 solution prepared as above was added and the columns were incubated overnight at room

232 temperature. After overnight incubation, the desulphoglucosinolates (dGLS) were eluted from

233 the columns with deionised water $(3 \times 1 \mathrm{ml})$. The collected eluate was dried under constant $\mathrm{N}_{2}$

234 flow and re-dissolved in deionised water $(200 \mu \mathrm{L})$

235 Micellar Electrokinetic Capillary Chromatography

236 Analyses were performed using a CE capillary electrophoresis system (Agilent, Waldbronn,

237 Germany) equipped with diode array detector. All separations were performed on a fused

238 silica capillary (Agilent, Stevens Creek, CA; $75 \mathrm{~lm} \mathrm{ID,} 64.5 \mathrm{~cm}$ total length, $56 \mathrm{~cm}$ effective

239 length). Samples were injected from the anodic end of the capillary (vacuum injection, 50

240 mbar, $1 \mathrm{~s})$. The separation buffer consisted of sodium chlorate $(250 \mathrm{mM})$ and boric acid (200

$241 \mathrm{mM})$ at $\mathrm{pH} 8.5$; the separation was carried out at $12 \mathrm{kV}$ and $60{ }^{\circ} \mathrm{C}$. The capillary was

242 conditioned between each run sequentially with $1.0 \mathrm{M} \mathrm{NaOH}(3 \mathrm{~min}), 0.1 \mathrm{M} \mathrm{NaOH}(1 \mathrm{~min})$,

243 water (1 $\mathrm{min})$ and separation buffer $(5 \mathrm{~min})$. Detection was performed on column at 230 and

$244280 \mathrm{~nm}$. Data processing was carried out with Chemstation software (Agilent Waldbronn,

245 Germany). The quantity of desulfo-glucosinolates was estimated as the average of quantities

246 calculated by comparison of normalized area under the curve (area under the curve divided by

247 migration time) of each identified desulfo-glucosinolate peak with the normalized area under

248 the curve of glucotropaeolin (internal standard, from the laboratory collection). Identification 
249 of individual desulfo-glucosinolates was performed by calculating their migration time

250 relative to the migration time of glucotropaeolin and their PDA profile

251

252 Statistical analysis

253 Statistical analysis was carried out using SAS 9.1 (Cary, NC). Floret weight, total phenolic,

254 total flavonoid and glucosinolate data were analysed using an ANOVA mixed model 255 containing a contrast code to compare the fully organic (OS+OP) and fully conventional $256(\mathrm{CS}+\mathrm{CP})$ treatments as well the individual treatments and interactions (SAS 9.1). Pearson 257 correlation coefficients were calculated between total phenolics, flavonoids and mean floret 258 weights using SAS 9.1.

259

260

\section{RESULTS AND DISCUSSION}

\section{Yield and quality}

262 In crop production the main differences between organic and conventional growing systems 263 involve the use of organic manures and crop rotations instead of inorganic fertilizers; and 264 mechanical or biological methods (including naturally derived compounds) for pest-control 265 instead of synthetic pesticides. Thus it can be considered that organic and conventional 266 agriculture differ in two major respects - how the soil fertility is managed, and how pests are 267 managed. Both factors may impact on crop yield and quality.

268 Analysis of broccoli yield, total phenolic content and total flavonoid content is shown in 269 Table 3. Year showed a significant $(p<0.01)$ effect with some measures showing a year $x$ 270 treatment interaction therefore data for each year was analysed separately (Table 3). Floret 271 weight, quality and yield was higher in year 2 than in year 1 for both varieties. Mean floret 272 weight ranged from $230.6 \pm 20.3 \mathrm{~g}$ to $307.0 \pm 17.0 \mathrm{~g}$ in year 1 and was considerably higher at $273247.1 \pm 78.5 \mathrm{~g}$ to $449.2 \pm 19.9 \mathrm{~g}$ in year 2. Climate data for the trial site (Supplementary 
274 material, Table S1) shows the growing season in year 1 was overall slightly warmer but much

275 wetter than year 2 with excessive rainfall during the summer especially in July. In year 1 a

276 significant soil treatment effect on floret weight $(\mathrm{p}<0.01)$ was found, with crops grown with

277 the conventional soil (CS) treatment showing higher floret weights, however this effect was

278 not significant in year 2. This may be due to soil nutrient leaching and/or poor root

279 establishment in year 1 as a result of heavy rainfall. Since nutrients in conventionally

280 fertilized soil are more readily crop available, it is possible that rainfall effects were

281 exacerbated in the organically fertilized soil. Year 1 was a poor year for crop growth with

282 frequent heavy rain and this was reflected in lower mean floret weight across all treatments.

283 Year 2 was an improved year for crop production with a better yield seen for both varieties.

284 Variety 'Belstar' performed particularly well under improved climatic conditions with a more

285 typical level of rainfall in year 2 as indicated by the significant main effect of variety $286(\mathrm{p}=0.0242)$ in this year.

287 In both years infestations with caterpillars of Large White butterfly and Diamond-back moth

288 occurred throughout the crop and were effectively treated with Pyrethrum in the organic pest-

289 control (OP) plots and with Decis in the conventional pest-control (CP) plots. At harvest

290 broccoli florets were scored for incidence of insect or other damage, and fungal and bacterial

291 diseases prevalent in North Country Dublin including White Blister (Albugo candida) and

292 Wet Rot (Erwinia carotovora and Pseudemonas spp.). Levels of insect damage and disease

293 were generally low and were not different between treatments in either year.

294 Overall no significant differences in yield were found between fully organic (OS+OP) and 295 fully conventional (CS+CP) management in any year (Table 3). However a significant soil 296 treatment main effect was found for floret weight in year 1 only with lower weights recorded 297 for broccoli grown under organic soil management (OS). These data indicate that soil 298 treatment rather than pest-control was the primary driver of broccoli yield and quality. We 
299 suggest that under favourable conditions such as year 2, both organic and conventional

300 fertilizer performed well. But under stressful conditions (such as year 1) the conventional soil

301 (CS) treatment provided readily plant available mineral fertilizers which enabled these plants

302 to outperform those under organic soil (OS) treatment.

\section{Total phenolic and total flavonoid content}

304 Levels of total phenolics (Figure 1 and Table 3) in year 1 were in the range 267.0 $305 \pm 18.4 \mathrm{GAE} \mathrm{mg} / 100 \mathrm{~g}$ FW to $376.5 \pm 19.0 \mathrm{GAE} \mathrm{mg} / 100 \mathrm{~g} \mathrm{FW}$, and were considerably lower in 306 year 2, ranging from $69.3 \pm 11.5$ to $106.8 \pm 7.5 \mathrm{GAE} \mathrm{mg} / 100 \mathrm{~g} \mathrm{FW}$. Thus levels in year 2 equate 307 to around one third to one quarter of the levels found in year 1. Total flavonoid content 308 showed the reverse trend (Figure 2 and Table 3 ) and ranged from $5.6 \pm 1.1$ to $25.9 \pm 3.4 \mathrm{CE}$ $309 \mathrm{mg} / 100 \mathrm{FW}$ in year 1 , with higher levels in year 2 ranging from $23.8 \pm 3.5$ to $35.4 \pm 5.2 \mathrm{CE}$ $310 \mathrm{mg} / 100 \mathrm{FW}$ across treatments.

311 The major phenolic compounds found in broccoli include flavonols such as quercetin and 312 kaempferol glycosides, hydroxycinnamoyl derivatives and chlorogenic acids. ${ }^{22}$ Phenylalanine 313 ammonia lyase (PAL) the key entry point enzyme for synthesis of phenolic compounds is 314 well known to be up-regulated by stresses including UV light, low temperature, nutrient 315 deficiency, wounding and pest or pathogen attack. ${ }^{31}$ The branch pathway to flavonoid 316 synthesis is controlled by chalcone synthase (CHS). Flavonoid synthesis is commonly 317 reported to be up-regulated by light in several crops including broccoli. In a three year field 318 study which examined levels of the flavonols kaempferol and quercetin in three broccoli 319 varieties ('Marathon', 'Lord' and 'Fiesta') the level of total solar radiation over the growing 320 period had a significant effect on both flavonols with higher levels under increased radiation.

32120 We propose that the higher levels of total flavonoids in year 2 in this study are due to 322 higher light levels; whilst the high overall content of total phenolics in year 1 reflect increased 
323 production of phenolic acids in response to stress caused by heavy rainfall and associated 324 waterlogging of soils.

325 As with yield no significant differences in total phenolic or flavonoid content were 326 found between fully organic (OS+OP) and fully conventional $(\mathrm{CS}+\mathrm{CP})$ management in any 327 year (Table 3). However a significant soil treatment main effect was found for total phenolics 328 and total flavonoids in year 1 only. Data indicated that in a poor year for crop growth (year 1) 329 broccoli floret total phenolic and flavonoid content was increased when crops were grown in 330 organic soil (OS). We ascribe this result to nutrient stress of the plants grown in the OS 331 treatment. There was a significant strong positive correlation $(\mathrm{p}<0.001)$ in both years between 332 total phenolic content and flavonoid content with $\mathrm{r}=0.74$ in year 1 and $\mathrm{r}=0.69$ in year 2 .

333 The levels of total phenolics and flavonoids reported here are in agreement with levels 334 found in green broccoli varieties in other studies. ${ }^{13-16}$ Relatively few studies have compared 335 phenolic content in vegetable crops grown under conventional and organic systems and to our 336 knowledge no previous field trial studies have examined phenolic content in organic and 337 conventionally grown broccoli. A recent well controlled Danish study ${ }^{7}$ measured levels of 338 flavonoids in onions and phenolic acids in carrots and potatoes grown over two years using 339 either conventional or two types of organic system (cover crop fertility building or animal 340 manure based fertilizer regime). The predominant phenolic acid in potatoes (5-caffeoylquinic 341 acid) was significantly higher in the cover crop based organic system than in the conventional 342 system. $^{7}$ In contrast phenolic acids in carrot and flavonoids in onion showed a large year to 343 year variation but were not affected by production system. Our data indicate that total 344 phenolic and flavonoid content in broccoli shows significant year to year variation but is not 345 significantly different in fully organic (OS+OP) compared to fully conventional $(\mathrm{CS}+\mathrm{CP})$ 346 production systems. 


\section{Total and individual glucosinolate content}

349 Glucosinolate contents determined in broccoli samples are shown in Table 4. Peaks from all 350 samples were resolved and easy to identify (Figure 3). The desulfoglucosinolates from 351 broccoli were characterised by the presence of aliphatic glucosinolates and indol-3-yl 352 glucosinolates. Mainly aliphatic glucoinolates - glucoraphanin, glucobrassicin, and 353 neoglucobrassicin were the major components in most samples. 4-MeO-glucobrassicin was 354 found at lower levels and progoitrin and sinigrin were found inconsistently in trace amounts 355 in some samples. No evidence of glucoiberin nor 4-OH-glucobrassicin was found. Total 356 glucosinolate content ranged from 3.0 to $20.9 \mu \mathrm{mol} / \mathrm{g}$ DW and averages were in the range $357 \quad 8.1 \pm 0.7$ to $10.1 \pm 0.4 \mu \mathrm{mol} / \mathrm{g} \mathrm{DW}( \pm$ standard error, $\mathrm{n}=4$ ) depending on treatment. Previous 358 studies have shown that either glucoraphanin or glucobrassicin is the predominant 359 glucosinolate in broccoli. ${ }^{13-20,32-35}$ It is not yet well understood why in some studies one is in 360 higher proportion than the other and this may be due to genetic (i.e. differences between 361 cultivars) and/or environmental conditions (for review see ${ }^{36}$ ). In this study, the average

362 concentration ( \pm standard error, $n=4)$ of major glucosinolates across production systems and 363 over the two year period ranged from 1.8. \pm 0.2 to $3.3 \pm 0.3 \mu \mathrm{mol} / \mathrm{g} \mathrm{DW}$ for glucoraphanin, $3642.9 . \pm .0 .2$ to $4.7 \pm 0.3 \mu \mathrm{mol} / \mathrm{g}$ DW for glucobrassicin, $0.2 \pm 0.02$ to $0.4 \pm 0.03 \mu \mathrm{mol} / \mathrm{g}$ DM for 4 365 MeO-glucobrassicin and $1.4 \pm 0.2$ to $3.1 \pm 0.1 \mu \mathrm{mol} / \mathrm{g} \mathrm{DW}$ for neoglucobrassicin respectively.

366 This is in agreement with ranges of glucosinolates in broccoli previously reported. ${ }^{13,17}$ No 367 significant interaction or main effect of year on total or individual glucosinolate content was 368 observed across the two year period. This is important because a significant difference in the 369 content of secondary metabolites between years would indicate significant seasonal 370 environmental interactions in the glucosinolate profile. Variability in biochemical data 371 between years is often observed and is normally considered to be due to the crops response to 372 different climatic conditions. ${ }^{32-34}$ Differences in broccoli glucosinolate content due to 
373 environmental conditions, in particular temperature and irradiation levels, have been reported

374 in other studies. ${ }^{20,33}$ In the two seasons reported here, mean temperatures, humidity and wind

375 speed were similar in both years, but rainfall levels were almost double in year 1 relative to

376 year 2. Therefore rainfall levels do not appear to impact glucosinolate content. A number of

377 previous studies have indicated a significant genotype effect on glucosinolate profile in

378 broccoli. $^{13,17,34,35}$ Our data indicated levels of sinigrin were significantly higher $(\mathrm{p}<0.05)$ in $\mathrm{cv}$.

379 'Fiesta' than in cv. 'Belstar' across treatments and years. Conversely glucoraphanin and 4-

380 MeO-glucobrassicin were significantly higher $(\mathrm{p}<0.05)$ in cv. 'Belstar' than in cv. 'Fiesta'

381 across treatments and years (Figure 4 and Table 4). Glucoraphanin has been extensively

382 studied due to the potential bioactivity of its isothiocyanate breakdown product

383 sulforaphane. ${ }^{37}$ The finding of consistently higher levels in 'Belstar' is therefore of relevance

384 from a health perspective. Levels of 4-MeO-glucobrassicin were lower in both varieties and

385 its potential as bioactive compound has been less explored.

386 Glucobrassicin and neoglucobrassicin content was significantly $(\mathrm{p}<0.05)$ higher in

387 samples grown under fully organic treatment (organic soil and organic pest-control; OS+OP)

388 compared to samples grown under completely conventional treatment $(\mathrm{CS}+\mathrm{CP})$. Mixed model

389 ANOVA showed that no significant main or interaction effects were observed for different

390 soil treatments (Table 4). For neoglucobrassicin a significant variety by pest-control

391 interaction was seen. It is important to highlight that although glucobrassicin contents were

392 not significantly different for pest-control, values were near the $95 \%$ confidence threshold

$393 \quad(\mathrm{p}=0.067)$.

394 In terms of potential bioactivity the breakdown product of indolyl glucosinolates including 395 glucobrassicin and neoglucobrassicin is indole-3-carbinol (I3C). I3C and its condensation 396 product 3,3' diindolylmethane (DIM) have recently received considerable attention as anti-

397 carcinogenic compounds. They exhibit potent anti-tumor activity with low levels of toxicity 
398 in a wide range of human cancer cell lines. ${ }^{38,39}$ The finding of statistically significant higher

399 levels of glucobrassicin and neoglucobrassicin in broccoli grown under organic management 400 practices would appear to be especially robust since similar results were obtained in an earlier 401 basket study. ${ }^{9}$ In the study of Meyer et al. ${ }^{9}$ levels of individual glucosinolates were profiled 402 in market purchased broccoli obtained at monthly intervals over a 1 year period in Germany. 403 Results indicated no significant differences in glucoraphanin content, whilst 404 neoglucobrassicin and glucobrassicin were significantly higher $(p<0.01)$ in organic than in 405 conventional broccoli. The finding of similar results in two different types of study (market 406 study and field trial) strengthen the conclusion that the indolyl glucosinolates glucobrassicin 407 and neoglucobrassicin consistently occur at higher levels in organically grown broccoli across 408 different varieties and geographical locations.

\section{CONCLUSIONS}

411 Our data indicated that yield (mean floret weight), total phenolic and flavonoid 412 content in broccoli shows significant year on year variation, but is not significantly different 413 in organic $(\mathrm{OS}+\mathrm{OP})$ compared to conventional $(\mathrm{CS}+\mathrm{CP})$ production systems. We hypothesise 414 that in year 1 increased stress caused a generalised increase in total phenolic content via up415 regulation of PAL - the key enzyme controlling entry of metabolites into central 416 phenylpropanoid metabolism. We further hypothesise that since in year 2 environmental 417 conditions were more favourable, PAL was not up-regulated, however the chalcone synthase 418 controlled branch pathway into flavonoid synthesis, would be up-regulated by light. Thus 419 under these conditions a greater proportion of phenolic synthesis would be shunted towards 420 flavonoid synthesis. Further studies to investigate this hypothesis would be of interest.

421 In contrast total and individual glucosinolate content was unaffected by season, but 422 levels of two specific glucosinolates - glucobrassicin and neoglucobrassicin - were 
423 significantly higher in the fully organic production system. Levels of glucorophanin were also 424 consistently higher in variety 'Belstar' than in 'Fiesta'.

425 These data underscore the nuanced regulation of levels of bioactive compounds in crop plants. 426 It is becoming clear that plant foods contain a wide diversity of bioactive compounds which 427 may be affected by genotype, and also respond differently to the plant's environment 428 depending on the specific metabolite involved. We suggest that specific bioactive compounds 429 will be responsive to production practices used in either organic or conventional agriculture 430 whilst others will not. This complexity may account for much of the variability seen in 431 literature reviews and meta-analyses (e.g. 5, 40,41 ) comparing organic and conventional food, 432 and highlights the need for further well designed studies focussed on specific metabolites or 433 groups of metabolities in known crop varieties.

434

435

436 ACKNOWLEDGEMENTS

437 The authors thank Prof. Carlo Leifert, University of Newcastle (UK), Dr. Charles Merfield, 438 Christy Roberts and Leo Finn (Teagasc) for assistance in designing, implementing and 439 maintaining the field trial, and Prof. Hilmer Sørensen and Jens C. Sørensen, University of 440 Copenhagen (Denmark) for their help with MECC. The Irish Department of Agriculture, 441 Fisheries and Food (FIRM 06/NITAFRC6) is gratefully acknowledged for financial support 442 of this work. 
444 References

445 1. Falguera V, Aliguer N, Falguera M, An integrated approach to current trends in food 446 consumption: Moving toward functional and organic products? Food Control 26(2): 274-281 447 (2012).

448 2. Janssen M, Hamm U, Product labelling in the market for organic food: Consumer 449 preferences and willingness-to-pay for different organic certification logos. Food Quality and $450 \quad$ Preference 25(1): 9-22 (2012).

451 3. EU, Council Regulation (EC) No 834/2007 of 28th June 2007 on organic production 452 and labelling of organic products and repealing Regulation (EEC) No 2092/91 Official 453 Journal of the European Union, 20.7.2007.(2007).

454 4. EU, Council Regulation No. 2092/91 of 24th June on organic production of 455 agricultural products and indications referring thereto on agricultural products and foodstuffs. $456 \quad$ OJL 198 22.7.p.1 1991. (1991).

457 5. Dangour AD, Dodhia SK, Hayter A, Allen E, Lock K, Uauy R, Nutritional quality of 458 organic foods: a systematic review. American Journal of Clinical Nutrition 90(3): 680-685 459 (2009).

460 6. Soltoft M, Eriksen MR, Trager AWB, Nielsen J, Laursen KH, Husted S, Halekoh 461 U, Knuthsen P, Comparison of Polyacetylene Content in Organically and Conventionally 462 Grown Carrots Using a Fast Ultrasonic Liquid Extraction Method. Journal of Agricultural 463 and Food Chemistry 58(13): $7673-7679$ (2010).

464 7. Soltoft M, Nielsen J, Lauren KH, Husted S, Halekoh U, Knuthsen P, Effects of 465 Organic and Conventional Growth Systems on the Content of Flavonoids in Onions and 466 Phenolic Acids in Carrots and Potatoes. Journal of Agricultural and Food Chemistry 58(19): 467 10323-10329 (2010). 
468 8. Reganold JP, Andrews PK, Reeve JR, Carpenter-Boggs L, Schadt CW, Alldredge JR, 469 Ross CF, Davies NM, Zhou JZ, Fruit and Soil Quality of Organic and Conventional 470 Strawberry Agroecosystems. Plos One 5(9): e12346. doi:10.1371/journal.pone.0012346 471 (2010).

472 9. Meyer M, Adam ST, Comparison of glucosinolate levels in commercial broccoli and 473 red cabbage from conventional and ecological farming. European Food Research and 474 Technology 226(6): 1429-1437 (2008).

475 10. Chen P, Harnly JM, Lester GE, Flow Injection Mass Spectral Fingerprints 476 Demonstrate Chemical Differences in Rio Red Grapefruit with Respect to Year, Harvest 477 Time, and Conventional versus Organic Farming. Journal of Agricultural and Food 478 Chemistry 58(8): 4545-4553 (2010).

479 11. Magkos F, Arvaniti F, Zampelas A, Organic food: Buying more safety or just peace of 480 mind? A critical review of the literature. Critical Reviews in Food Science and Nutrition 46 481 (1): 23-56 (2006).

48212 Rembialkowska E, Quality of plant products from organic agriculture. Journal of the 483 Science of Food and Agriculture 87: 2757-2762 (2007).

484 13. Vallejo F, Tomas-Barberan FA, Garcia-Viguera C, Potential bioactive compounds in 485 health promotion from broccoli cultivars grown in Spain. Journal of the Science of Food and 486 Agriculture 82(11): 1293-1297 (2002).

487 14. Gliszczynska-Swiglo A, Kaluzewicz A, Lemanska K, Knaflewski M, Tyrakowska B, 488 The effect of solar radiation on the flavonol content in broccoli inflorescence. Food Chemistry 489 100(1): 241-245 (2007).

490 15. Robbins RJ, Keck AS, Banuelos G, Finley JW, Cultivation conditions and selenium 491 fertilization alter the phenolic profile, glucosinolate, and sulforaphane content of broccoli. 492 Journal of Medicinal Food 8(2): 204-214 (2005). 
493 16. Vallejo F, Garcia-Viguera C, Tomas-Barberan FA, Changes in broccoli (Brassica

494 oleracea L. var. italica) health-promoting compounds with inflorescence development. 495 Journal of Agricultural and Food Chemistry 51(13): 3776-3782 (2003).

496 17. Kushad M, Brown AF, Kurilich AC, Juvik JA, Klein BP, Wallig MA, Jeffery EH,

497 Variation of glucosinolates in vegetable crops of Brassica oleracea. Journal of Agricultural 498 and Food Chemistry 47(4): 1541-1548 (1999).

499 18. Jones RB, Imsic M, Franz P, Hale G, Tomkins RB, High nitrogen during growth 500 reduced glucoraphanin and flavonol content in broccoli (Brassica oleracea var. italica) heads. 501 Australian Journal of Experimental Agriculture 47: 1498-1505 (2007).

502 19. Cartea ME, Velasco P, Obregon S, Padilla G, de Haro A, Seasonal variation in 503 glucosinolate content in Brassica oleracea crops grown in northwestern Spain. 504 Phytochemistry 69: 403-410 (2008).

505 20. Schonhof I, Klaring HP, Krumbein A, Claussen W, Schreiner M, Effect of 506 temperature increase under low radiation conditions on phytochemicals and ascorbic acid in 507 greenhouse grown broccoli. Agriculture Ecosystems \& Environment 119(1-2): 103-111 508 (2007).

509 21. Jones RB, Effects of postharvest handling conditions and cooking on anthocyanin, 510 lycopene, and glucosinolate content and bioavailability in fruits and vegetables. New Zealand 511 Journal of Crop and Horticultural Science 35(2): 219-227 (2007).

512 22. Winkler S, Faragher J, Franz P, Imsic M, Jones R., Glucoraphanin and flavonoid 513 levels remain stable during simulated transport and marketing of broccoli (Brassica oleracea 514 var. italica) heads. Postharvest Biology and Technology 43(1): 89-94 (2007).

515 23. Lester GE, Manthey JA, Buslig BS, Organic vs. Conventionally Grown Rio Red 516 Whole Grapefruit and Juice: Comparison of Production Inputs, Market Quality, Consumer 
517 Acceptance, and Human Health-Bioactive Compounds. Journal of Agricultural and Food

518 Chemistry 55: 4474-4480 (2007).

519 24. Soltoft M, Nielsen J, Laursen KH, Effects of Organic and Conventional Growth 520 Systems on the Content of Flavonoids in Onions and Phenolic Acids in Carrots and Potatoes.

521 Journal of Agricultural and Food Chemistry 58: 10323-10329 (2010).

522 25. Lalor S, Coulter B, Major and minor micronutrient advice for productive agricultural 523 crops. 3rd ed. Teagasc, Oakpark, Carlow, 2008.

524 26. Alexander S, Approved Pesticides for use on vegetable crops 2011. Teagasc, 525 Kinsealy, Dublin 17, 2011.

526 27. Gardiner M.J, National vegetable and glasshouse crops research centre Kinsealy, 527 Malahide, Co. Dublin. Soil Survey Bulletin 3: 1-8, 1963.

528 28. Reilly K, Cullen E, Lola-Luz T, Stone D, Valverde J, Gaffney, M., Brunton, N, Grant

529 J, Griffiths B, Effect of organic, conventional and mixed cultivation practices on soil

530 microbial community structure and nematode abundance in a cultivated onion crop.

531 Journal of the Science of Food and Agriculture 93(15): 3700-3709 (2013).

532 29. Marinova D, Ribarova F, Atanassova M, Total phenolics and total flavonoids in 533 Bulgarian fruits and vegetables. J. Univ. Chem. Tech. Met. 40(3): 255-260 (2005).

534 30. Hernandez-Hierro JM, Valverde J, Villacreces S, Reilly K, Gaffney M, Gonzalez535 Miret ML, Heredia FJ, Downey G, Feasibility Study on the Use of Visible-Near Infrared 536 Spectroscopy for the Screening of Individual and Total Glucosinolate Contents in Broccoli 537 Journal of Agricultural and Food Chemistry 60: $7352-7358$ (2012).

538 31. Naoumkina MA, Zhao QA, Gallego-Giraldo L, Dai XB, Zhao PX, Dixon RA, 539 Genome-wide analysis of phenylpropanoid defence pathways. Molecular Plant Pathology $540 \quad$ 11(6): 829-846 (2010). 
541 32. Brown AF, Yousef GG, Jeffrey EH, Klein BP, Wallig MA, Kushad M, Juvik JA,

542 Glucosinolate profiles in broccoli: Variation in levels and implications in breeding for cancer

543 chemoprotection. Journal of the American Society for Horticultural Science 127(5): 807-813

544 (2002).

545 33. Krumbein A, Schonhof I, Influence of temperature and irradiation on glucosinolates in 546 broccoli heads. Biologically Active Phytochemicals in Food 269: 477-479 (2001).

547 34. Schreiner M, Vegetable crop management strategies to increase the quantity of 548 phytochemicals. European Journal of Nutrition 44 (2): 85-94 (2005).

549 35. Schonhof I, Krumbein A, Brückner B, Genotypic effects on glucosinolates and 550 sensory properties of broccoli and cauliflower. Food 48: 25-33 (2004).

551 36. Reilly K, On-farm and fresh produce management, in Handbook of plant food 552 phytochemicals: sources stability and extraction, ed. by Tiwari, BK, Brunton N, Brennan C. 553 Wiley-Blackwell Publishing, pp. 201-225 (2012).

554 37. Zhang Y, Tang L, Discovery and development of sulforaphane as a cancer 555 chemopreventive phytochemical. Acta Pharmacologica Sinica 28(9): 1343-1354 (2007).

556 38. Marconett CN, Sundar SN, Tseng M, Tin AS, Tran KQ, Mahuron KM, Bjeldanes 557 LF, Firestone GL, Indole-3-carbinol down-regulation of telomerase gene expression requires 558 the inhibition of estrogen receptor-alpha and Sp1 transcription factor interactions within the 559 hTERT promoter and mediates the G(1) cell cycle arrest of human breast cancer cells. 560 Carcinogenesis 32(9): 1315-1323 (2011).

56139 Khuda-Bukhsh AR, Das S, Saha SK, Molecular Approaches Toward Targeted 562 Cancer Prevention with Some Food Plants and Their Products: Inflammatory and Other 563 Signal Pathways. Nutrition and Cancer 66(2): 194-205 (2014). 
564 40. Hoefkens C, Sioen I, Baert K, et al., Consuming organic versus conventional 565 vegetables: The effect on nutrient and contaminant intakes. Food and Chemical Toxicology

566 48(11): 3058-3066 (2010).

567 41. Hunter D, Foster M, McArthur JO et al., Evaluation of the Micronutrient Composition 568 of Plant Foods Produced by Organic and Conventional Agricultural Methods. Critical 569 Reviews in Food Science and Nutrition (51)6: 571-582 (2011).

570

571

572

573 
FIGURES
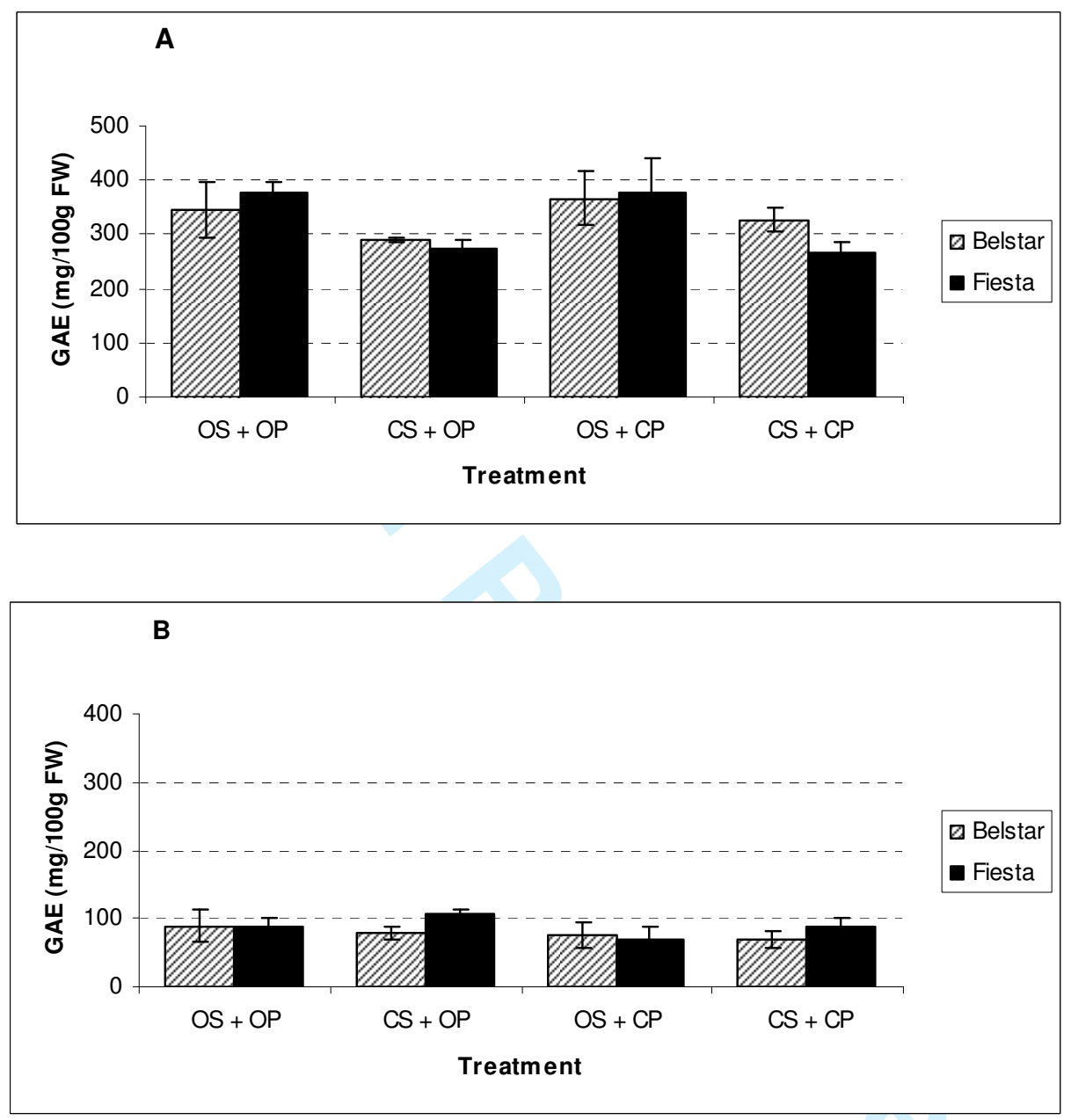

Figure 1. Total phenolic content (GAE mg/100g FW) in broccoli cv. 'Belstar' and cv. 'Fiesta' under different treatment combinations and in two harvest years (Panel A: year 1 and panel B: year 2). OS+OP means fully organic treatment and CS+CP means fully conventional treatment. Treatment codes: OS = organic soil treatment, $\mathrm{CS}=$ conventional soil treatment, $\mathrm{OP}=$ organic pest-control, $\mathrm{CP}=$ conventional pest-control. Bars show the mean and standard error of field replicates $(n=4)$. 


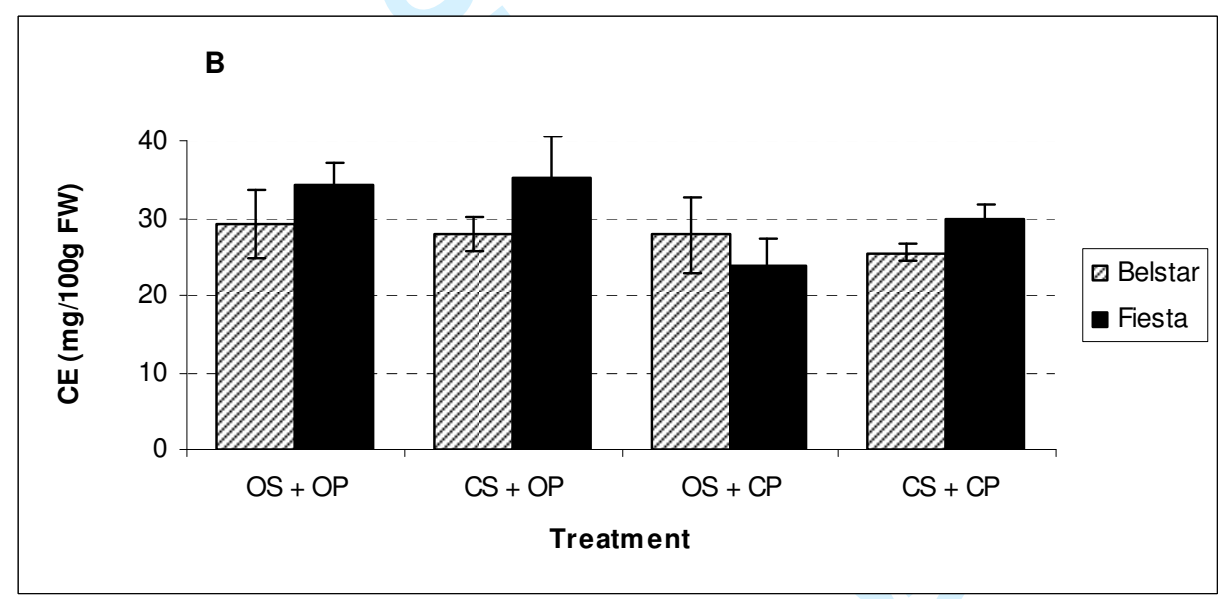

Figure 2. Total flavonoid content (CE mg/100g FW) in broccoli cv. 'Belstar' and cv. 'Fiesta' under different treatment combinations and in two harvest years (Panel A: year 1 and panel B: year 2). OS+OP means fully organic treatment and $\mathrm{CS}+\mathrm{CP}$ means fully conventional treatment. Treatment codes: OS = organic soil treatment, $\mathrm{CS}=$ conventional soil treatment, $\mathrm{OP}=$ organic pest-control, $\mathrm{CP}=$ conventional pest-control. Bars show the mean and standard error of field replicates $(n=4)$. 


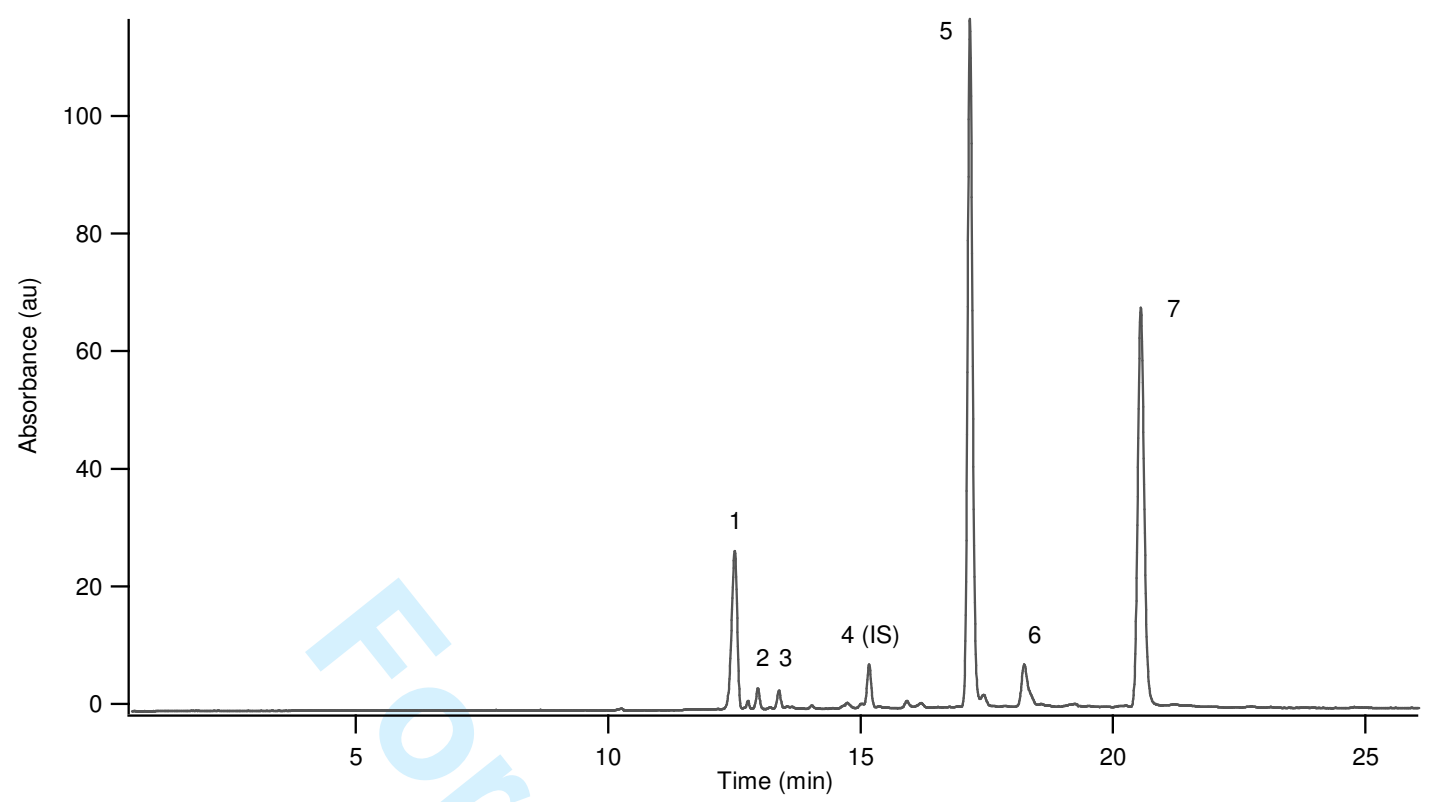

Figure 3. Representative electrochromatogram of desulfo-glucosinolates from broccoli. Each number above the peak represents a major identified desulfo-glucosinolate. 1- desulfoglucoraphanin; 2-;desulfo-protoitrin; 3- desulfo-sinigrin; 4- desulfo-glucotropaeolin (used as internal standard); 5- desulfo-glucobrassicin; 6- desulfo-4MeO-glucobrassicin; 7- desulfoneoglucobrassicin. 

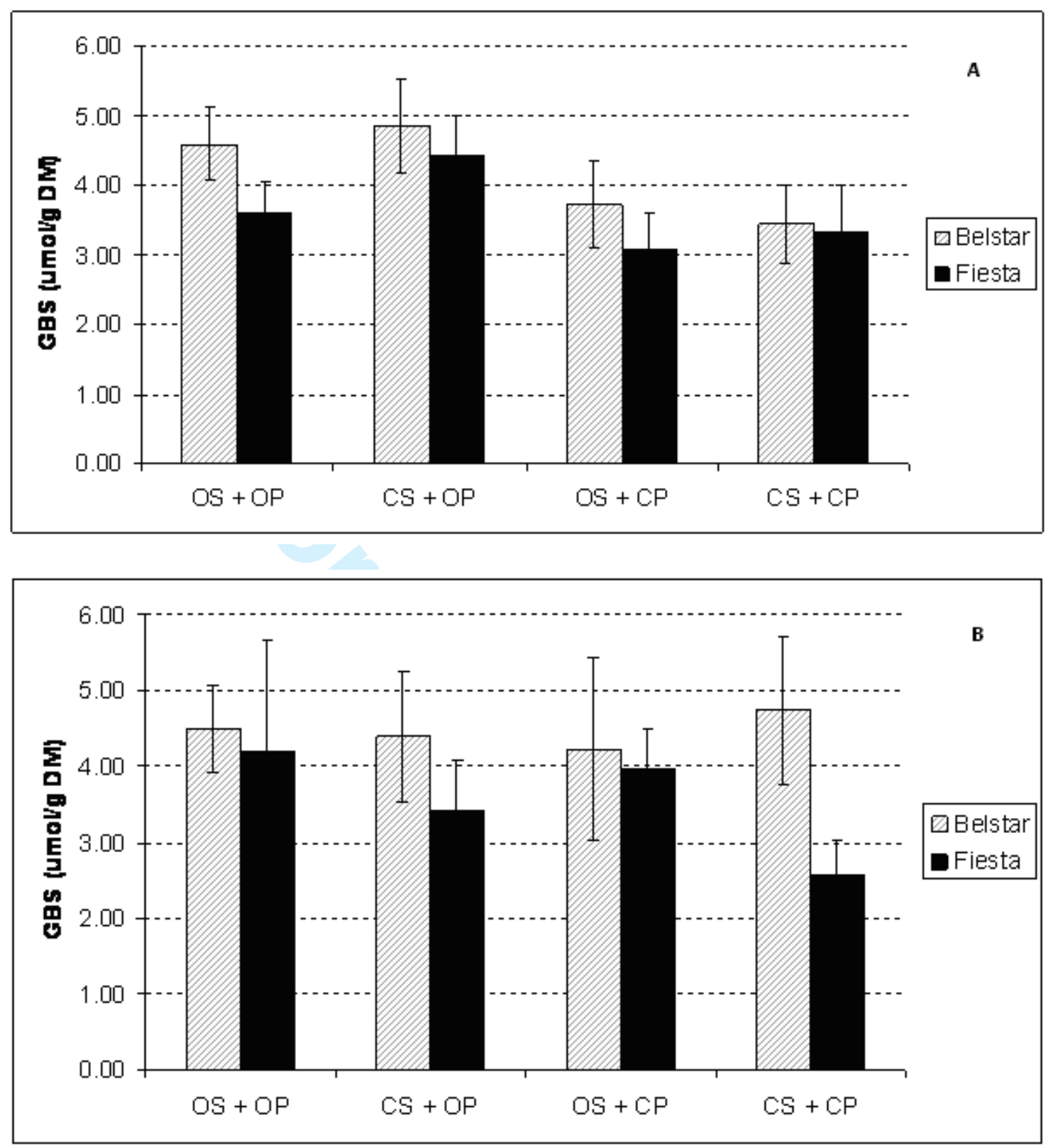

Figure 4. Average concentrations $(\mu \mathrm{mol} / \mathrm{g} \mathrm{DW})$ of desulfo-glucobrassicin under different treatment combinations and two harvest years (Panel A: year 1 and panel B: year 2). OS+OP means fully organic treatment and CS+CP means fully conventional treatment. Treatment codes: $\mathrm{OS}=$ organic soil treatment, $\mathrm{CS}=$ conventional soil treatment, $\mathrm{OP}=$ organic pestcontrol, $\mathrm{CP}=$ conventional pest-control. Bars show the mean and standard error of field replicates $(n=4)$. 

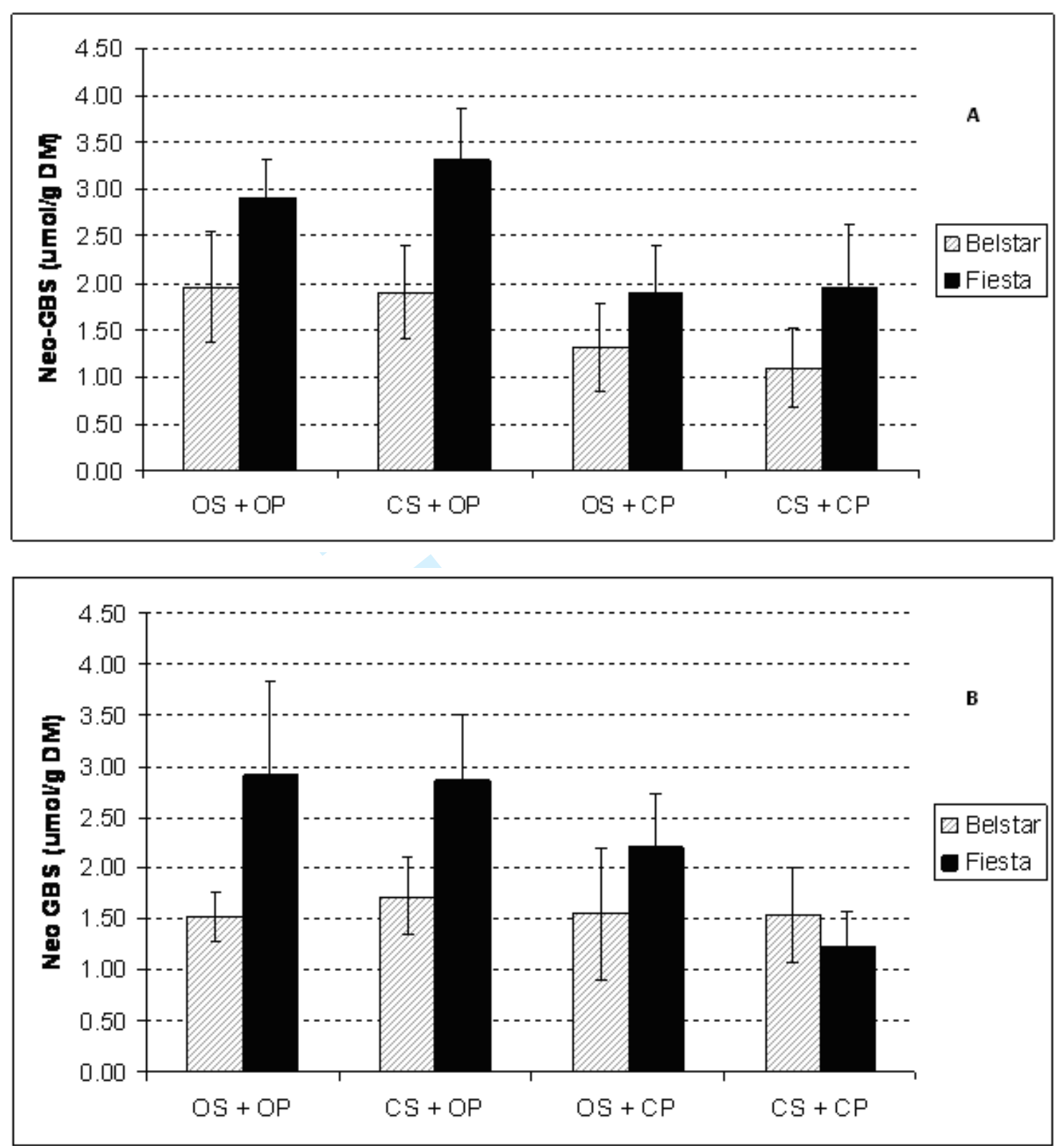

Figure 5. Average concentrations ( $\mu \mathrm{mol} / \mathrm{g} \mathrm{DW})$ of desulfo-neoglucobrassicin under different treatment combinations and two harvest years (Panel A: year 1 and panel B: year 2). OS+OP means fully organic treatment and $\mathrm{CS}+\mathrm{CP}$ means fully conventional treatment. Treatment codes: $\mathrm{OS}=$ organic soil treatment, $\mathrm{CS}=$ conventional soil treatment, $\mathrm{OP}=$ organic pestcontrol, $\mathrm{CP}=$ conventional pest-control. Bars show the mean and standard error of field replicates $(n=4)$. 


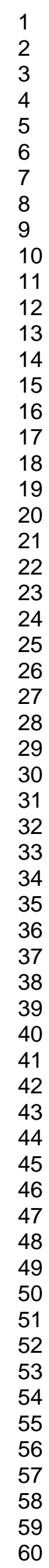




\section{TABLES}

Table 1. Different agricultural management treatments applied in this study.

\begin{tabular}{|c|c|c|}
\hline & Organic & Conventional \\
\hline Soil treatment & $\begin{array}{l}\text { Four year rotation: ley (red } \\
\text { clover) } \rightarrow \text { broccoli } \rightarrow \\
\text { onion } \rightarrow \text { carrot } \\
\text { - Additional organic } \\
\text { fertilization as indicated by } \\
\text { soil test } \\
\text { - Winter cover crop }\end{array}$ & 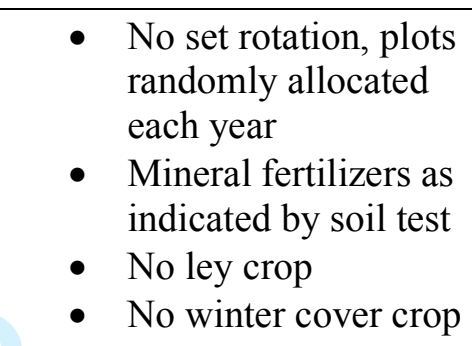 \\
\hline $\begin{array}{l}\text { Pest-control } \\
\text { treatment }\end{array}$ & $\begin{array}{l}\text { - } \text { Certified organic seed } \\
\text { - } \text { Refuge area } \\
\text { - } \text { Mechanical pest-control } \\
\text { - Weed control by mechanical } \\
\text { methods } \\
\text { - Certified organic treatments } \\
\text { (e.g. garlic spray) }\end{array}$ & $\begin{array}{l}\text { - Chemically treated } \\
\text { seed } \\
\text { - Chemical weed } \\
\text { control (herbicides) } \\
\text { - chemical pest - } \\
\text { control (fungicides } \\
\text { and insecticides) }\end{array}$ \\
\hline
\end{tabular}


25

26

27

29

30

31

33

34

35

36

37

38

39

40

41

42
43

44

45

46

47

48

49

51

52

53

54

55

57

58

59

60 
1 Table 2. Specific pest-control and soil treatments used for broccoli cultivation in the Teagasc

2 Kinsealy Systems Comparison trial in 2009 (year1) and 2010 (year 2).

\section{PEST-CONTROL TREATMENT}

YEAR 1 (2009)

YEAR 2 (2010)

Organic Pest-control (OP)

\section{SOIL}

\section{TREATMENT}

Organic $\underline{\text { Soil }}$ treatment (OS)

Conventional Pestcontrol (CP)
ECOguard garlic spray modular drench ${ }^{3}$ $\left(4 \% \mathrm{v} / \mathrm{v}\right.$ at $2 \mathrm{~L} / \mathrm{m}^{2}$ ) Brassica collars Mechanical weeding (hand hoeing). Pyrethrum 5EC ${ }^{3}(1.1 \mathrm{~L} / \mathrm{ha})$

Dursban modular drench ${ }^{3}(50 \mathrm{ml}$ per 5000 modules), Roundup ${ }^{1}$ (4L/ha), Stomp (3.3L/ha), Butisan $S^{1}(1.5 \mathrm{~L} / \mathrm{ha})$, Aramo ${ }^{1}$ $(1.5 \mathrm{~L} / \mathrm{ha})$, Decimate $^{1} \quad 20 \mathrm{~L} / \mathrm{ha}$, Decis $^{3}$ $(300 \mathrm{ml} / \mathrm{ha})$

Previous crop - grass set aside $>10$ years

$$
\begin{aligned}
& \text { N } 115 \mathrm{~kg} / \mathrm{ha} \\
& \text { P } 64 \mathrm{~kg} / \mathrm{ha} \\
& \text { K } 180 \mathrm{~kg} / \mathrm{ha} \\
& \text { B } 11 \mathrm{~kg} / \mathrm{ha}
\end{aligned}
$$

Applied as Greenvale plant food (4.5:3:3) (pelleted chicken manure + calcified seaweed), ProKali (3:0:14) and Solubor. A top dress equivalent to $20 \mathrm{~kg} / \mathrm{ha} \mathrm{N}$ was applied on 14th August.

Conventional Soil treatment (CS)

Previous crop - grass set aside $>10$ years

$$
\begin{aligned}
& \text { N } 115 \mathrm{~kg} / \mathrm{ha} \\
& \text { P } 64 \mathrm{~kg} / \mathrm{ha} \\
& \text { K } 180 \mathrm{~kg} / \mathrm{ha} \\
& \text { B } 11 \mathrm{~kg} / \mathrm{ha}
\end{aligned}
$$

Applied as CAN $(27 \%$ N), Single superphosphate $(7.8 \% \mathrm{P})$, Sulphate of potash $(42 \% \mathrm{~K})$ and Solubor. A top dress equivalent to $20 \mathrm{~kg} / \mathrm{ha} \mathrm{N}$ was applied on 14th August.
ECOguard garlic spray modular drench $^{3}\left(4 \% \mathrm{v} / \mathrm{v}\right.$ at $\left.2 \mathrm{~L} / \mathrm{m}^{2}\right)$

Brassica collars

Mechanical weeding (hand hoeing). Pyrethrum $5 \mathrm{EC}^{3}(1.1 \mathrm{~L} / \mathrm{ha})$

Proplant modular drench $(2.4 \mathrm{ml}$ in $0.8 \mathrm{~L}$ per 216 tray), Dursban modular drench ${ }^{3}(50 \mathrm{ml}$ per 5000 modules), Roundup ${ }^{1} \quad(4 \mathrm{~L} / \mathrm{ha})$, Stomp (3.3L/ha), Butisan $\mathrm{S}^{1}$ (1.5L/ha), Stratos Ultra ${ }^{1}$ (3L/ha), $\operatorname{Decis}^{3}(300 \mathrm{ml} / \mathrm{ha})$

Previous crop - Red clover (2009)

$\mathrm{N} 115 \mathrm{~kg} / \mathrm{ha}$

P $64 \mathrm{~kg} / \mathrm{ha}$

$\mathrm{K} 180 \mathrm{~kg} / \mathrm{ha}$

B $11 \mathrm{~kg} / \mathrm{ha}$

Applied as Greenvale plant food (4.5:3:3) (pelleted chicken manure + calcified seaweed), ProKali (3:0:14) and Solubor.

Previous crop - Any (2009)

$\mathrm{N} 115 \mathrm{~kg} / \mathrm{ha}$

$\mathrm{P} 64 \mathrm{~kg} / \mathrm{ha}$

K $180 \mathrm{~kg} / \mathrm{ha}$

B $11 \mathrm{~kg} / \mathrm{ha}$

Applied as CAN (27\% N), Single superphosphate $(7.8 \% \mathrm{P})$, Sulphate of potash $(42 \% \mathrm{~K})$ and Solubor.

$3 \quad{ }^{1}$ Herbicide, ${ }^{2}$ Fungicide, ${ }^{3}$ Insecticide. 


1
2
3
4
5
6
7
8
9
10
11
12
13
14
15
16
17
18
19
20
21
22
23
24
25
26
27
28
29
30
31
32
33
34
35
36
37
38
39
40
41
42
43
44
45
46
47
48
49
50
51
52
53
54
55
56
57
58
60

25

26

27

28
29

30

31

33

34

35

37

38

39

40

41

42

44

45

46

47

48

49

51

52

53

54

55

57

58

59

60 


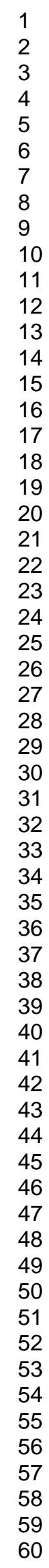


Table 3. Broccoli floret weight, total phenolic and total flavonoid content under different management practices.

\section{Mean floret weight (g) Total phenolic content Total flavonoid content (GAE mg/100g FW) (CE mg/100g FW)}

\begin{tabular}{|c|c|c|c|c|c|c|}
\hline Treatment: & Year 1 & Year 2 & Year 1 & Year 2 & Year 1 & Year 2 \\
\hline $\mathrm{V1}+\mathrm{OS}+\mathrm{OP}$ & $252.9 \pm 27.2$ & $442.3 \pm 19.9$ & $345.7 \pm 51.3$ & $88.5 \pm 24.0$ & $16.6 \pm 6.9$ & $29.2 \pm 4.5$ \\
\hline $\mathrm{V} 1+\mathrm{CS}+\mathrm{OP}$ & $268.4 \pm 22.3$ & $383.3 \pm 20.8$ & $290.8 \pm 3.9$ & $79.3 \pm 9.6$ & $10.2 \pm 1.8$ & $27.9 \pm 2.2$ \\
\hline $\mathrm{V} 1+\mathrm{OS}+\mathrm{CP}$ & $235.8 \pm 12.3$ & $449.2 \pm 19.9$ & $365.9 \pm 50.2$ & $74.9 \pm 19.1$ & $25.9 \pm 3.4$ & $27.8 \pm 4.9$ \\
\hline $\mathrm{V} 1+\mathrm{CS}+\mathrm{CP}$ & $293.2 \pm 33.7$ & $363.1 \pm 19.5$ & $326.8 \pm 22.4$ & $69.3 \pm 11.5$ & $17.2 \pm 3.1$ & $25.6 \pm 1.2$ \\
\hline $\mathrm{V} 2+\mathrm{OS}+\mathrm{OP}$ & $230.6 \pm 20.3$ & $300.0 \pm 7.3$ & $376.5 \pm 19.0$ & $87.6 \pm 13.5$ & $17.8 \pm 6.0$ & $34.3 \pm 2.8$ \\
\hline $\mathrm{V} 2+\mathrm{CS}+\mathrm{OP}$ & $307 . \pm 17.0$ & $247.1 \pm 78.5$ & $273.4 \pm 16.0$ & $106.8 \pm 7.5$ & $5.6 \pm 1.1$ & $35.4 \pm 5.2$ \\
\hline $\mathrm{V} 2+\mathrm{OS}+\mathrm{CP}$ & $253.7 \pm 8.5$ & $327.2 \pm 24.3$ & $375.6 \pm 63.0$ & $70.2 \pm 19.1$ & $22.0 \pm 7.3$ & $23.8 \pm 3.5$ \\
\hline $\mathrm{V} 2+\mathrm{CS}+\mathrm{CP}$ & $293.9 \pm 41.4$ & $363.9 \pm 15.2$ & $267.0 \pm 18.4$ & $86.7 \pm 15.4$ & $11.9 \pm 2.1$ & $29.8 \pm 2.0$ \\
\hline \multicolumn{7}{|c|}{ Statistical significance: } \\
\hline \multicolumn{7}{|c|}{ ANOVA p values: } \\
\hline Replicate & 0.9501 & 0.7573 & 0.9645 & 0.1610 & 0.4220 & 0.5511 \\
\hline variety & 0.5924 & 0.0242 & 0.7736 & 0.3971 & 0.5049 & 0.4315 \\
\hline soil & 0.0060 & 0.0775 & 0.0135 & 0.5927 & 0.0152 & 0.6748 \\
\hline pest-control & 0.9044 & 0.3604 & 0.7419 & 0.2070 & 0.1627 & 0.1025 \\
\hline variety $\mathbf{x}$ soil & 0.4692 & 0.1507 & 0.2991 & 0.2031 & 0.6107 & 0.2284 \\
\hline variety $x$ pest-control & 0.9785 & 0.0845 & 0.5692 & 0.7178 & 0.6720 & 0.1655 \\
\hline soil $x$ pest-control & 0.9329 & 0.4742 & 0.9263 & 0.9814 & 0.9793 & 0.6376 \\
\hline $\begin{array}{l}\text { variety } x \text { soil } x \text { pest- } \\
\text { control }\end{array}$ & 0.2049 & 0.1905 & 0.8488 & 0.8701 & 0.7489 & 0.4929 \\
\hline $\begin{array}{l}\text { fully conventional vs. } \\
\text { fully organic }\end{array}$ & 0.1698 & 0.8379 & 0.1600 & 0.4662 & 0.6037 & 0.1995 \\
\hline
\end{tabular}

Data shown are mean \pm standard error of the mean $(n=4)$. OS + OP means fully organic treatment and CS $+C P$ means fully conventional treatment. Since the difference between years was significant data for individual years is shown separately. Treatment codes: $\mathrm{V} 1=\mathrm{cv}$. 'Belstar', $\mathrm{V} 2=\mathrm{cv}$. 'Fiesta' OS = organic soil treatment, CS = conventional soil treatment, $\mathrm{OP}=$ organic pest-control, $\mathrm{CP}=$ conventional pest-control. ANOVA $\mathrm{p}$ values in bold are significant at $\mathrm{p}<0.05$. 
Table 4. Broccoli total and individual glucosinolate content ( $\mu \mathrm{mol} / \mathrm{g} \mathrm{DW})$ under different management practices.

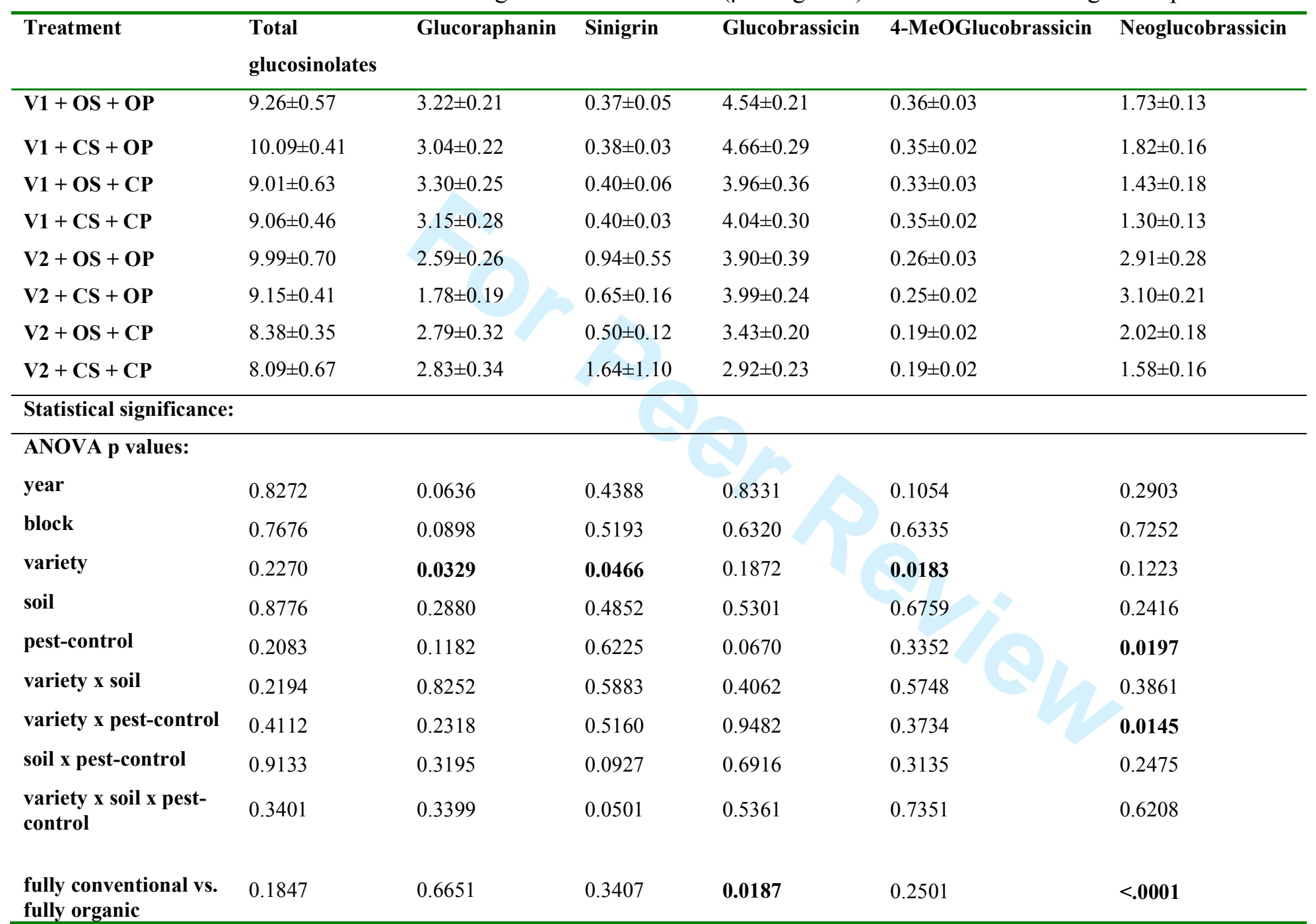

\section{fully organic}

Data shown are mean \pm standard error of total and individual glucosinolates over two trial years $((\mu \mathrm{mol} / \mathrm{g} \mathrm{DW})$. OS $+\mathrm{OP}$ means fully organic treatment and CS $+\mathrm{CP}$ means fully conventional treatment. Treatment codes: Variety V1= 'Belstar', V2 = 'Fiesta' ; OS = organic soil treatment, CS = conventional soil treatment; OP = organic pestcontrol, $\mathrm{CP}=$ conventional pest-control. ANOVA $\mathrm{p}$ values shown in bold are significant at $\mathrm{p}<0.05$ 


\section{Page 39 of 44}

Journal of the Science of Food and Agriculture 
1 Supplementary material. Table S1. Climatic conditions during broccoli crop production in 22009 and 2010. $\mathrm{T}=$ Mean temperature $\left({ }^{\circ} \mathrm{C}\right), \mathrm{TM}=$ Mean maximum temperature $\left({ }^{\circ} \mathrm{C}\right), \mathrm{Tm}=$ 3 Mean minimum temperature $\left({ }^{\circ} \mathrm{C}\right), \mathrm{H}=$ Mean humidity $(\%), \mathrm{V}=$ Mean wind speed $(\mathrm{Km} / \mathrm{h})$, $4 \quad \mathrm{RA}=$ Daily indicator for occurrence of rain or drizzle (total days), PP $=$ Total monthly 5 precipitation amount $(\mathrm{mm})$.

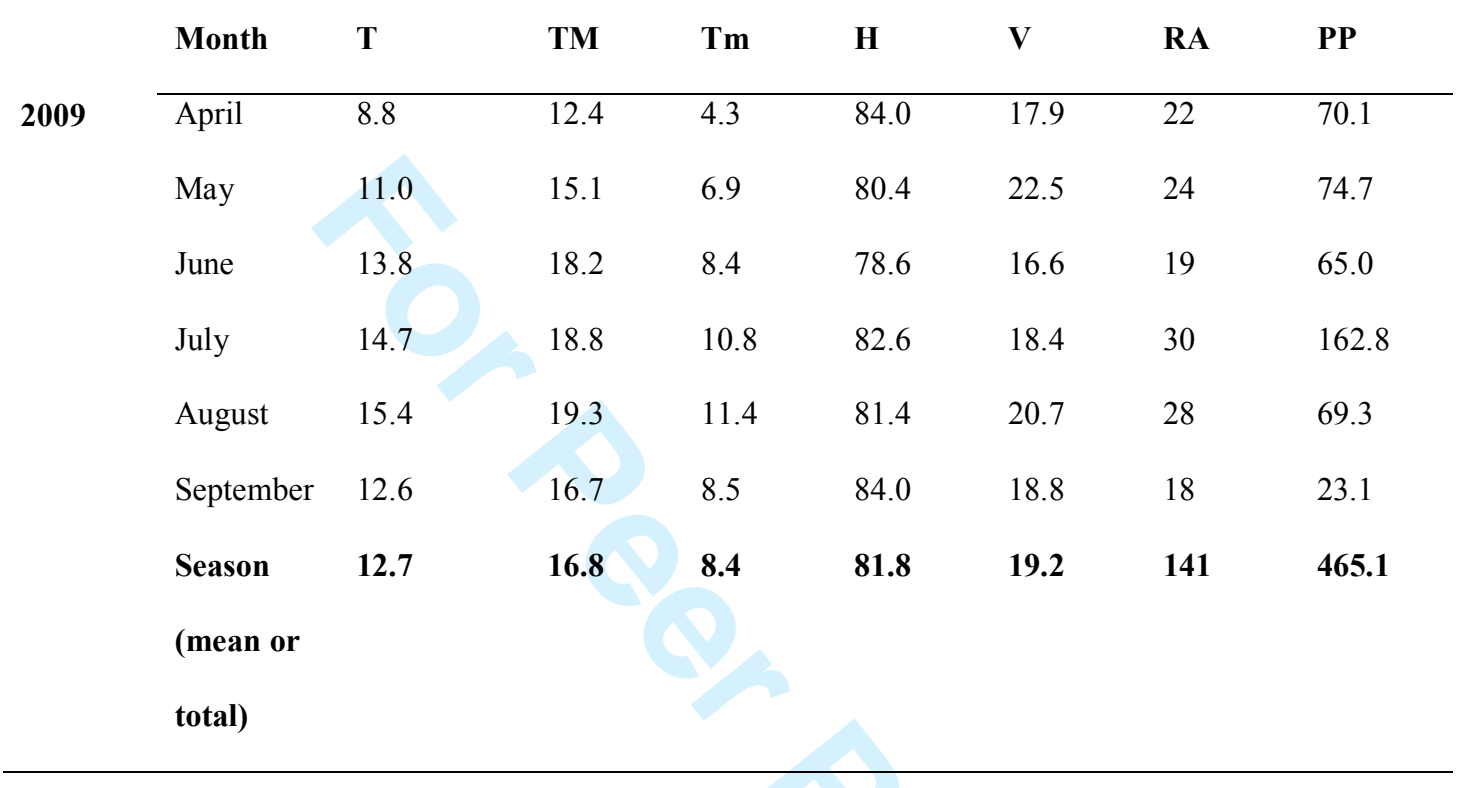

\begin{tabular}{lllllllll} 
& Month & T & TM & Tm & H & V & RA & PP \\
\cline { 2 - 8 } & March & 5.2 & 9.7 & 0.1 & 81.1 & 17.2 & 17 & 55.6 \\
April & 8.1 & 12.9 & 2.5 & 78.1 & 15.6 & 14 & 26.7 \\
May & 10.2 & 14.7 & 4.8 & 78.3 & 15.3 & 20 & 29.2 \\
June & 14.5 & 19.2 & 8.9 & 78.8 & 14.5 & 17 & 57.4 \\
July & 15.7 & 19.6 & 12.1 & 80.4 & 19.5 & 28 & 76.7 \\
August & 14.0 & 18.3 & 9.6 & 80.8 & 17 & 22 & 47.5 \\
Season & $\mathbf{1 1 . 3}$ & $\mathbf{1 5 . 7}$ & $\mathbf{6 . 3}$ & $\mathbf{7 9 . 6}$ & $\mathbf{1 6 . 5}$ & $\mathbf{1 1 8}$ & $\mathbf{2 9 3 . 1}$ \\
(mean or & & & & & & & &
\end{tabular}

6

7

8 


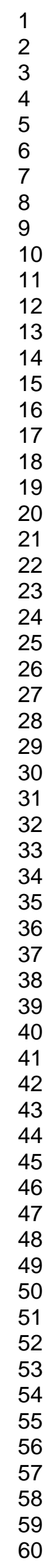




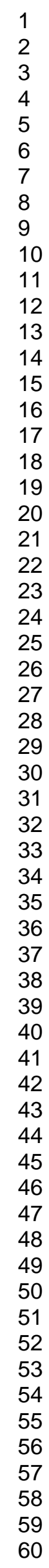


Supplementary material. Figure S1. Diagram showing the Kinsealy Systems Comparison Trial in Year 1. V1 = Variety $1, \mathrm{~V} 2=$ Variety 2 (for broccoli V1 = 'Belstar', V2 = 'Fiesta'). CP = Conventional pest-control treatment, $\mathrm{OP}=$ Organic pest-control treatment. $\mathrm{CS}=$ Conventional soil treatment, $\mathrm{OS}=$ Organic soil treatment. Dark grey areas indicate $1 \mathrm{~m}$ wide grass inter-plot areas. Light grey indicates permanent refuge areas planted with buckwheat, vetch, borage, sunflower, coriander, fennel, cornflower, corn marigold, cocksfoot grass to encourage beneficial insects as part of the OP treatment. Note: Crops within the organic soil treatment (OS) move each year according to a set rotation (Ley $\rightarrow$ broccoli $\rightarrow$ onion $\rightarrow$ carrot). Crops within conventional soil treatment (CS) do not follow a set rotation pattern and move randomly, taking into account practices of commercial growers e.g. onion 4 year gap before returning to same land ( 1 in every 4). The "other" crop used in CS plots in year 1 was wheat (Triticum aestivum) and in year 2 was lettuce (Lactuca sativa). 
Year 2: Kinsealy Systems Comparison Trial
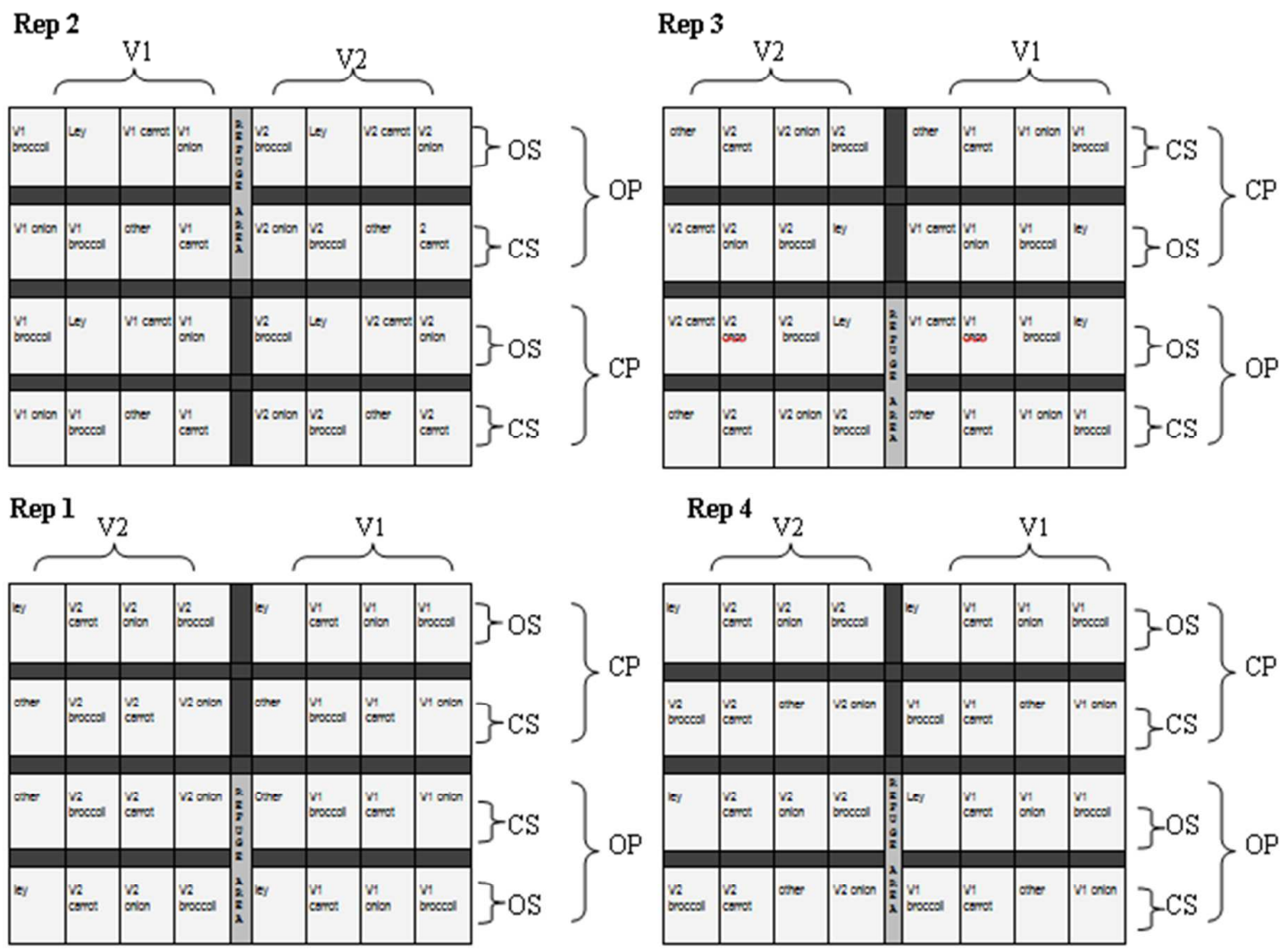

Supplementary material. Figure S2. Diagram showing the Kinsealy Systems Comparison Trial in Year 2. V1 = Variety $1, \mathrm{~V} 2=$ Variety 2 (for broccoli V1 = 'Belstar', V2 = 'Fiesta'). CP = Conventional pest-control treatment, $\mathrm{OP}=$ Organic pest-control treatment. $\mathrm{CS}=$ Conventional soil treatment, $\mathrm{OS}=$ Organic soil treatment. Dark grey areas indicate $1 \mathrm{~m}$ wide grass inter-plot areas. Light grey indicates permanent refuge areas planted with buckwheat, vetch, borage, sunflower, coriander, fennel, cornflower, corn marigold, cocksfoot grass to encourage beneficial insects as part of the OP treatment. Note: Crops within the organic soil treatment (OS) move each year according to a set rotation (Ley $\rightarrow$ broccoli $\rightarrow$ onion $\rightarrow$ carrot). Crops within conventional soil treatment (CS) do not follow a set rotation pattern and move randomly, taking into account practices of commercial growers e.g. onion 4 year gap before returning to same land (1 in every 4$)$. The "other" crop used in CS plots in year 1 was wheat (Triticum aestivum) and in year 2 was lettuce (Lactuca sativa). 